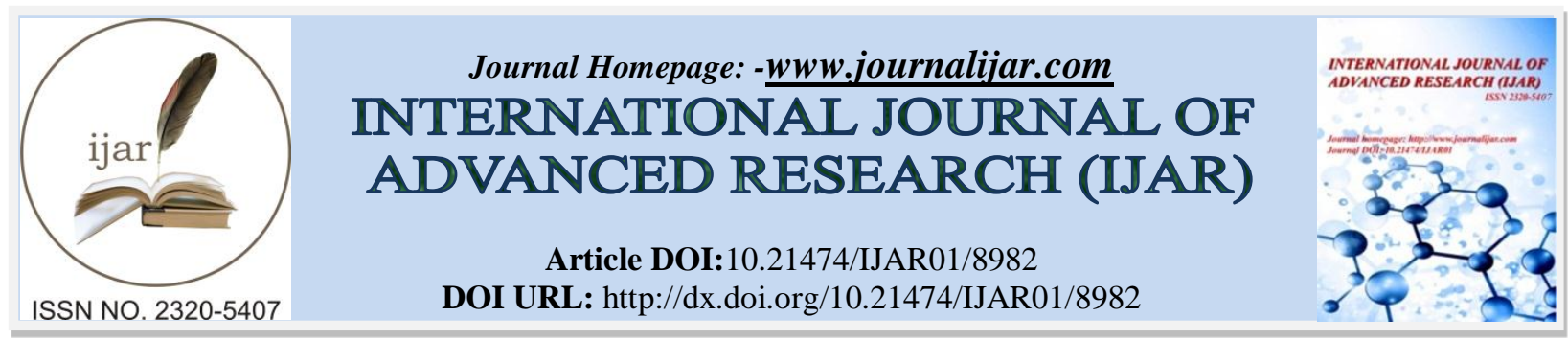

RESEARCH ARTICLE

\title{
THE EFFECT OF AUSTEMPERING HEAT TREATMENTS ON THE MICROSTRUCTURE AND CORROSION BEHAVIOR OF CAST IRON IN 3.5\% SODIUM CHLORIDE SOLUTION.
}

\author{
A.A. Nofal ${ }^{1}$, Amal S. I. Ahmed ${ }^{2}$, W. A. Ghanem ${ }^{1}$, W. A. Hussein ${ }^{2}$ and N. K. El-dabaa ${ }^{2}$. \\ 1. Central Metallurgical Research and Development Institute (CMRDI), Tepen, Cairo, Egypt. \\ 2. Chemistry Department, Faculty of Science (Girls), Al-Azhar University, Nasr City, Cairo, Egypt.
}

\section{Manuscript Info}

\section{Manuscript History}

Received: 25 February 2019

Final Accepted: 27 March 2019

Published: April 2019

Key words:-

Corrosion, Heat treatment, Austempering ductile iron, Potentiodynamic polarization.

\section{Abstract}

Background: Austempered ductile iron (ADI) is an interesting class of materials because of their unique microstructure containing a multiphase matrix (called ausferrite), graphite spheres and oxide inclusions, the need to investigate the effect of austempering heat treatment on corrosion behavior of it.

Results: The outcomes demonstrated that heat treatment is very powerful method for improving the corrosion resistance of ductile cast iron. Since the microstructure of the heat treated samples was austempered ferrite.

Conclusions: The corrosion resistance of $\mathrm{ADI}$ heat treated at $\left(375^{\circ} \mathrm{C}\right)$ is higher than $\mathrm{ADI}$ heat treated at $\left(325^{\circ} \mathrm{C}\right)$ because the microstructural modifications induced by austempering at $375^{\circ} \mathrm{C}$ which results to a greater coarsening of the austenite grain and broad ferrite needles.

Copy Right, IJAR, 2019,. All rights reserved.

\section{Introduction:-}

Austempered ductile iron (ADI) is a new ferrous material made from ductile iron with austempered heat treatment, and possesses many advantages such as low cost, high strength, good toughness, vibration resistance, wear resistance and fatigue resistance, etc. [1]. The ductility of austempered ductile iron depends mostly on relative amount of austenite. Attractive mechanical properties, low cost make ADI competitive not only to conventional ductile iron but also with cast steel and in some cases even aluminum alloys [2]. The austempering treatment allows ductile iron to have the strength and wear resistance comparable to wrought steels while retaining the low cost and design flexibility of cast irons [3]. The excellent property combination of ADI has opened new horizons for cast iron to replace steel castings and forgings in many engineering applications with considerable cost benefits [4]. Austempered ductile irons are an interesting class of materials because of their unique microstructure and interesting properties. When subjected to austempering treatment ductile iron transforms to a microstructure consisting of ferrite and stabilized austenite rather than ferrite and carbide as in austempered steels [5-6].Microstructure and properties of ADI are dependent especially on temperature of isothermal transformation of austenite and holding time at this temperature [7]. We would like to reveal some light on corrosion behavior of austempered ductile cast iron. The present study investigated austempering heat treatment of ductile iron, conducting corrosion tests in a constant concentration of $3.5 \% \mathrm{NaCl}$ and investigating the microstructural changes that occur in the samples after immersion in these media. 


\section{Methods:-}

Materials:-

The ductile iron material used for this study was cast in casting department of Central Metallurgical Research and Development Institute (CMRDI) and its chemical composition was determined with the aid of spectrometer, using spark analysis, as shown in Table 1.

\begin{tabular}{|c|c|c|c|c|c|c|}
\hline elements & $\mathrm{C}$ & $\mathrm{Si}$ & $\mathrm{Mn}$ & $\mathrm{S}$ & $\mathrm{Mg}$ & $\mathrm{CE} \%$ \\
\hline composition & 3.7 & 2.4 & $<\mathbf{0 . 2}$ & 0.015 & 0.05 & 4.5 \\
\hline
\end{tabular}

Table 1:-Percentage chemical composition of ductile iron sample

\section{Heat treatment cycle}

In order to obtain ADI material in this work. The heat treatment was carried out as follows: (1) austenitized in the range of $\left(810-930^{\circ} \mathrm{C}\right)$ for $75 \mathrm{~min}$.; then (2) quenched in a salt bath in the range of (232$400^{\circ} \mathrm{C}$ ), carried out very rabidly to avoid the formation of pearlite. The austempering stage completed at the desired temperatures $\left(325\right.$ and $\left.375^{\circ} \mathrm{C}\right)$ for 75 minutes to produce a matrix of needles of ferrite and enriched carbon austenite and finally (3) air-cooled to room temperature. A schematic heat-treating process is depicted in Fig. 1.

\section{Techniques}

After heat treatment specimens were tested for determined the corrosion rate by electrochemical techniques employed include open circuit potential (OCP), Potentiodynamic polarization and electrochemical impedance spectroscopy (EIS) using Volta Lab 40 (PGZ301) - Radiometer analytical. The surface morphology of the different specimen after the corrosion tests were examined Using SEM Model Quanta 250 FEG (Field Emission Gun) attached with EDX Unit (Energy Dispersive X-ray Analyses)

\section{Results and discussion:- Open circuit potential}

In this part the potential-time curves of the test electrodes which austempered at $\left(325^{\circ} \mathrm{C} \mathrm{\&} 375^{\circ} \mathrm{C}\right)$. Figure (2) show the open circuit potential of austempered ductile cast iron electrodes with time in $3.5 \% \mathrm{NaCl}$ solution. Inspection of these curves show that a general tendency for open circuit potential to shift from positive to negative values. This may be attributed to the destruction of pre-immersion oxide film present on the surface of electrodes. The negative shift in steady state potential $\left(E_{S . S}\right)$, indicates that $\mathrm{Cl}^{-}$accelerate the anodic metal dissolution reaction. By comparing the values of immersion potential $\left(\mathrm{E}_{\mathrm{imm}}\right)$ and steady state potential $\left(\mathrm{E}_{\mathrm{s.s}}\right)$ for $\mathrm{ADI}$ electrodes in $3.5 \%$ sodium chloride solution was tabulated in table (2)

Table 2:-Values of $\mathrm{E}_{\mathrm{imm} .}$ and $\mathrm{E}_{\mathrm{s} . \mathrm{s}}$ for $\mathrm{ADI}$ Electrodes in $3.5 \% \mathrm{NaCl}$ solution.

\begin{tabular}{|c|c|c|}
\hline \multirow{3}{*}{ Samples } & \multicolumn{2}{|c|}{$3.5 \%$} \\
\hline & $\mathbf{E}_{\text {imm. }}(\mathbf{m V})$ & $\mathbf{E}_{\mathrm{s} . \mathrm{s}}(\mathrm{mV})$ \\
\hline & -595.27 & -647.74 \\
\hline $\mathrm{ADI}\left(375^{\circ} \mathrm{C}\right)$ & -501.59 & -532.28 \\
\hline
\end{tabular}

Potentiodynamic polarization measurements

The Potentiodynamic polarization of austempered ductile cast iron electrodes were started at -1100 up to300 $\mathrm{mV}$ with calomel as a reference electrode. The rate of which the potential of the electrode is varied, $\mathrm{dv} / \mathrm{dt}$, has a considerable influence of the polarized curve. Good reproducibility was obtained with scanning rate $2 \mathrm{mV} / \mathrm{sec}$. Figure (3) represents the anodic and cathodic Potentiodynamic polarization curve for electrodes in $3.5 \% \mathrm{NaCl}$. This indicates that the corrosion resistance of ADI $\left(375^{\circ} \mathrm{C}\right)$ is higher than ADI $\left(325^{\circ} \mathrm{C}\right)$. The changes obtained in the corrosion resistance was related to the microstructural modifications induced by austempering at $375^{\circ} \mathrm{C}$ which results to a greater coarsening of the austenite grain and broad ferrite needles [8]. The two phases in ADI (ferrite and retained austenite) could act as electrochemical cell and aid corrosion. Since low temperatures ADI $\left(325^{\circ} \mathrm{C}\right)$ have a fine structure, the two phases are so closely spaced that there are a number of such cells in a small area. Thus, the surface area available for corrosion is large in low temperature ADI than the high temperature $\mathrm{ADI}\left(375^{\circ} \mathrm{C}\right)$ [9]. $^{\circ}$ 
Corrosion behavior results from an anodic process, corresponding to iron dissolution and a cathodic process, considered as the reduction of dissolved oxygen [5]. The electrochemical parameters such as $\mathrm{E}_{\text {corr. }}, \mathrm{I}_{\text {corr. }}, \beta_{\mathrm{a}}, \beta_{\mathrm{c}}$ and corrosion rate are tabulated in table (3).

Table 3:-Corrosion parameters for ADI electrodes in 3.5\% NaCl solution

\begin{tabular}{|c|c|c|c|c|c|}
\hline Electrodes & \multirow{2}{*}{$\begin{array}{c}\mathrm{E}_{\text {corr. }} \\
(\mathrm{V})\end{array}$} & $\begin{array}{c}\mathrm{I}_{\text {corr. }} \mathrm{x} 10^{-3} \\
\left(\mathrm{~A} / \mathrm{cm}^{2}\right)\end{array}$ & \multicolumn{2}{|c|}{ Tafel slopes } & \multirow{2}{*}{$\begin{array}{c}\text { Corrosion rate } \\
\mu \mathrm{m} / \mathrm{y}\end{array}$} \\
\cline { 4 - 5 } & -709.3 & 36.071 & 286.7 & -310.5 & 421.9 \\
\hline ADI $325^{\circ} \mathrm{C}$ & -554.3 & 25.52 & 231.9 & -411.3 & 29.85 \\
\hline ADI $375^{\circ} \mathrm{C}$ & $\mathrm{B}_{\mathrm{a}}(\mathrm{mv})$ & $\mathrm{B}_{\mathrm{c}}(\mathrm{mv})$ & \\
\hline
\end{tabular}

\section{Electrochemical impedance spectroscopy (EIS)}

Electrochemical impedance is widely used for investigation of the corrosion processes. This method is an influential application in obtaining more information on the kinetics of the electrode processes and on the surface properties of the system investigated. The impedance data points of the electrodes in $3.5 \% \mathrm{NaCl}$ solution were analyzed using the equivalent circuit shown in fig.(4). This equivalent circuit which has been previously reported fitted well with our experimental results.

The impedance diagrams in the figure (5) shows that the charge transfer resistance of two electrodes of ADI increase with increasing austempering heat temperature. Electrochemical theory shows that the reciprocal of the charge transfer resistance is proportional to the corrosion rate [10]. The main parameters deduced from the analysis of Nyquist diagram are the charge transfer Rct (diameter of high frequency loop) and the capacitance of double layer $\mathrm{C}_{\mathrm{dl}}$. The charge transfer $\mathrm{R}_{\mathrm{ct}}$ and double layer capacitance $\mathrm{C}_{\mathrm{dl}}$ values calculated for all test electrodes are given in table (4).

Table 4:-Impedance parameters for ADI sample in 3.5\% $\mathrm{NaCl}$ solution

\begin{tabular}{|l|c|c|}
\hline Samples & $\mathrm{R}_{\mathrm{ct}}\left(\mathrm{Kohm}_{\mathrm{cm}}{ }^{2}\right)$ & $\mathrm{C}_{\mathrm{dl}}\left(\mu \mathrm{F} / \mathrm{Cm}^{2}\right)$ \\
\hline ADI $325^{\circ} \mathrm{C}$ & 401.5 & 216.8 \\
\hline ADI $375^{\circ} \mathrm{C}$ & 686.4 & 23.18 \\
\hline
\end{tabular}

From the impedance data given in table (4), the value of $\mathrm{R}_{\mathrm{ct}}$ increases in the order:

ADI $325^{\circ} \mathrm{C}<$ ADI $375^{\circ} \mathrm{C}$

This can be attributed to the formation of protecting film on alloy / solution interface.

On the opposite hand, the high $\mathbf{R}_{\mathrm{ct}}$ values are usually related to lower corroding sample. The value of double layer capacitance $\mathrm{C}_{\mathrm{dl}}$ decreases in the order:

$$
\text { ADI } 325^{\circ} \mathrm{C}>\text { ADI } 375^{\circ} \mathrm{C}
$$

This attributed to extend in thickness of electrical double layer $[4,11]$.

\section{Spectroscopic analysis}

SEM analysis was used to define the morphology of surface attack on ADI samples. The scanning electron microscope images were recorded in Figs $(6,7)$ to establish the interaction of different components of the metal molecules with the metal surface after exposure in $3.5 \% \mathrm{NaCl}$. Figure (6) shows SEM micrographs of ADI samples before polarization test. The final microstructure of ADI casting is determined by the austempering stage, in which, two stage phase transformation reactions take place [4]. In the first stage, austenite $(\gamma)$ decomposes into ferrite $(\alpha)$ and high carbon content or untransformed austenite $(\gamma \mathrm{HC})$ :

Stage I Reaction: $\gamma \mathrm{C} \rightarrow \alpha+\gamma \mathrm{HC} \quad$ (toughening)

In the second stage, the high carbon austenite $(\gamma \mathrm{HC})$ decomposes into ferrite $(\alpha)$ and $\varepsilon$-carbide. The presence of $\varepsilon$-carbide is due to the too long holding time at austempering temperature and must be avoided because it results in the embrittlement of the matrix:

Stage II Reaction: $\gamma \mathrm{HC} \rightarrow \alpha+\varepsilon$-carbide (embrittlement) $[4,11]$. 
Figure (6) indicates that during holding at isothermal temperatures of $325^{\circ} \mathrm{C}$ or $375^{\circ} \mathrm{C}$, the high temperature austenite is discomposed in ausferrite. The ausferritic structure is a mixture of ferrite and high carbon austenite with an acicular morphology. It can be appreciated that as the heating temperature increases, the volume percent of ausferrite increases. The increase on the amount of ausferrite is associated to a decrease of volume percent of pro-eutectoid ferrite in the matrix.

Figure (7) shows SEM micrographs of ADI samples after polarization test. The image reveals the attack around the graphite nodules, which was attributed to the chlorides. This attack could be associated with the silicon content in this material, which increased its susceptibility to localized corrosion in the presence of chlorides. Chlorides are known to be a strong agent of corrosion, which usually attack metallic materials by forming pits. Closer examination of this image shows small holes (pits) around graphite and interdendritic carbides [12].

Figure (8) represent the EDAX spectra of ADI in 3.5\% $\mathrm{NaCl}$ solution. The results of XRAD examination suggest that the iron oxide is the main component of corrosion products.

\section{Conclusions:-}

The present study aims to show the effect of austempering heat treatment on the electrochemical behavior and microstructure of cast iron. Electrochemical techniques showed that:

1. Heat treatment is very powerful tool for improving the corrosion resistance. Because the microstructure of the heat treated samples was austempered ferrite.

2. The corrosion resistance of ADI heat treated at $\left(375^{\circ} \mathrm{C}\right)$ is higher than ADI heat treated at $\left(325^{\circ} \mathrm{C}\right)$ because the microstructural modifications induced by austempering at $375^{\circ} \mathrm{C}$ which results to a greater coarsening of the austenite grain and broad ferrite needles.

3. 3-At low temperatures of austempering $\left(325^{\circ} \mathrm{C}\right)$, the greater overcooling leads to highly refined ausferrite.

4. 4-At high temperatures of austempering $\left(375^{\circ} \mathrm{C}\right)$, the overcooling falls and the diffusivity of carbon increases which it helps to the growth of needles of ferrite and high carbon austenite. It results in a coarse ausferrite structure.

\section{Acknowledgements:-}

All authors acknowledge the CMRDI Labs for making the analysis on it.

\section{Funding}

Financial support made by CMRDI, Egypt, is gratefully acknowledged.

\section{Availability of data and materials}

All data generated or analyzed during this study are included in this published article info.

\section{Authors' contributions}

All authors read and approved the final manuscript.

Ethics approval and consent to participate

Manuscript does not contain studies involving human participants, human data, or human tissue.

\section{Consent for publication}

Not applicable

\section{Competing interests}

The authors declare that they have no competing interests. 


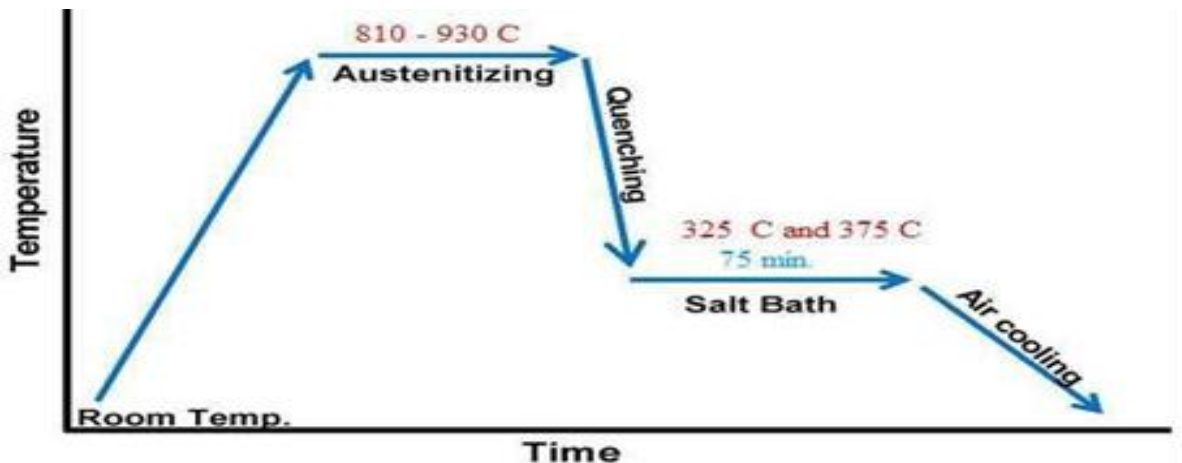

Time

Figure 1:-Heat treatment diagram of ductile iron

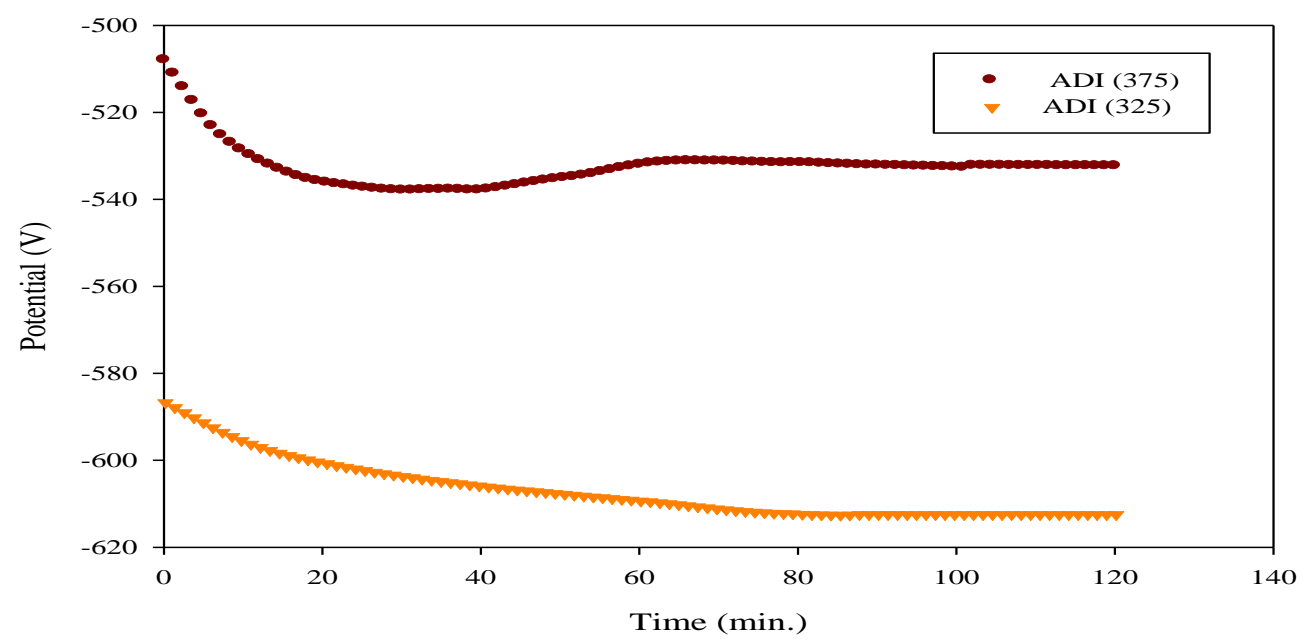

Fig 2:-Potential / Time curve of ADI electrodes in 3.5\% NaCl

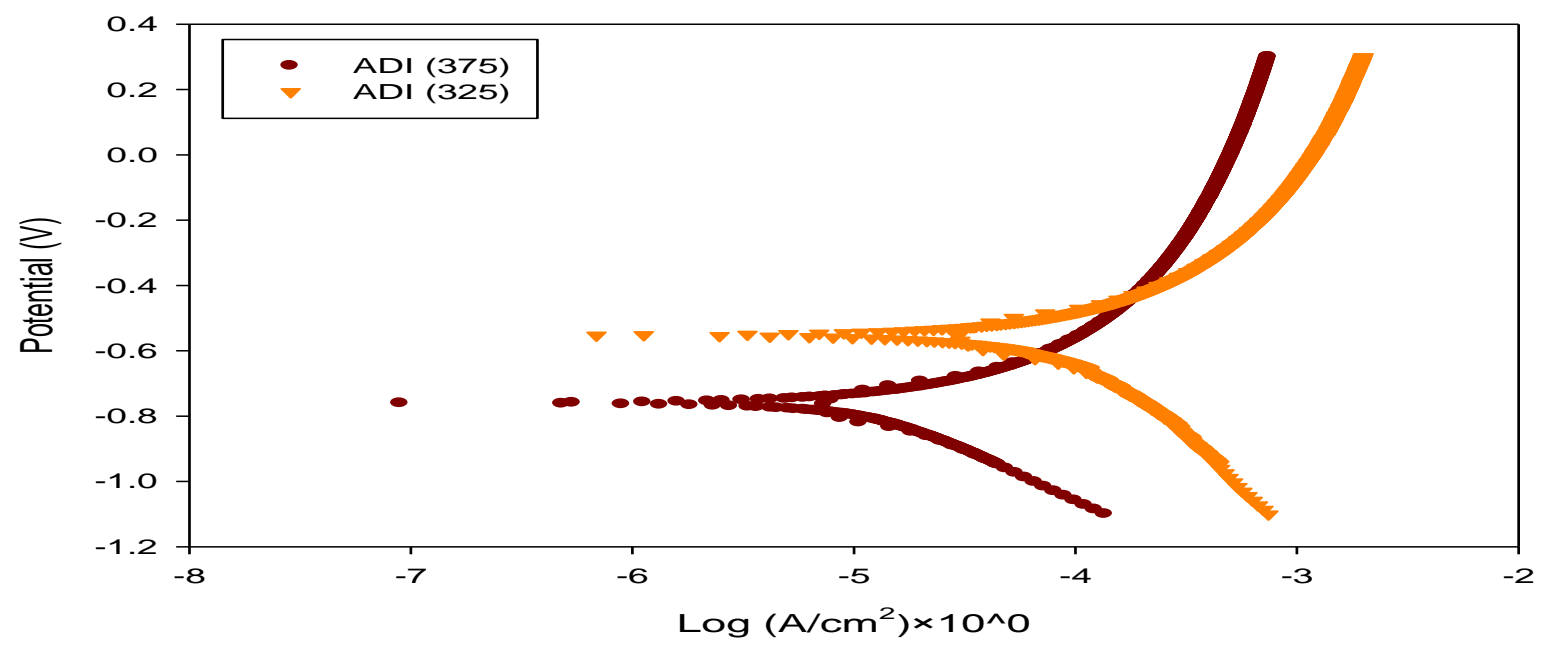

Fig (3): Anodic and cathodic Potentiodynamic polarization curves for ADI electrodes in $3.5 \% \mathrm{NaCl}$ solution 


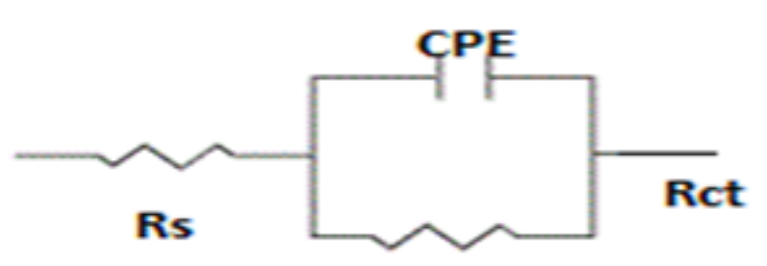

Fig 4:-Suggested equivalent circuit model for the studied system

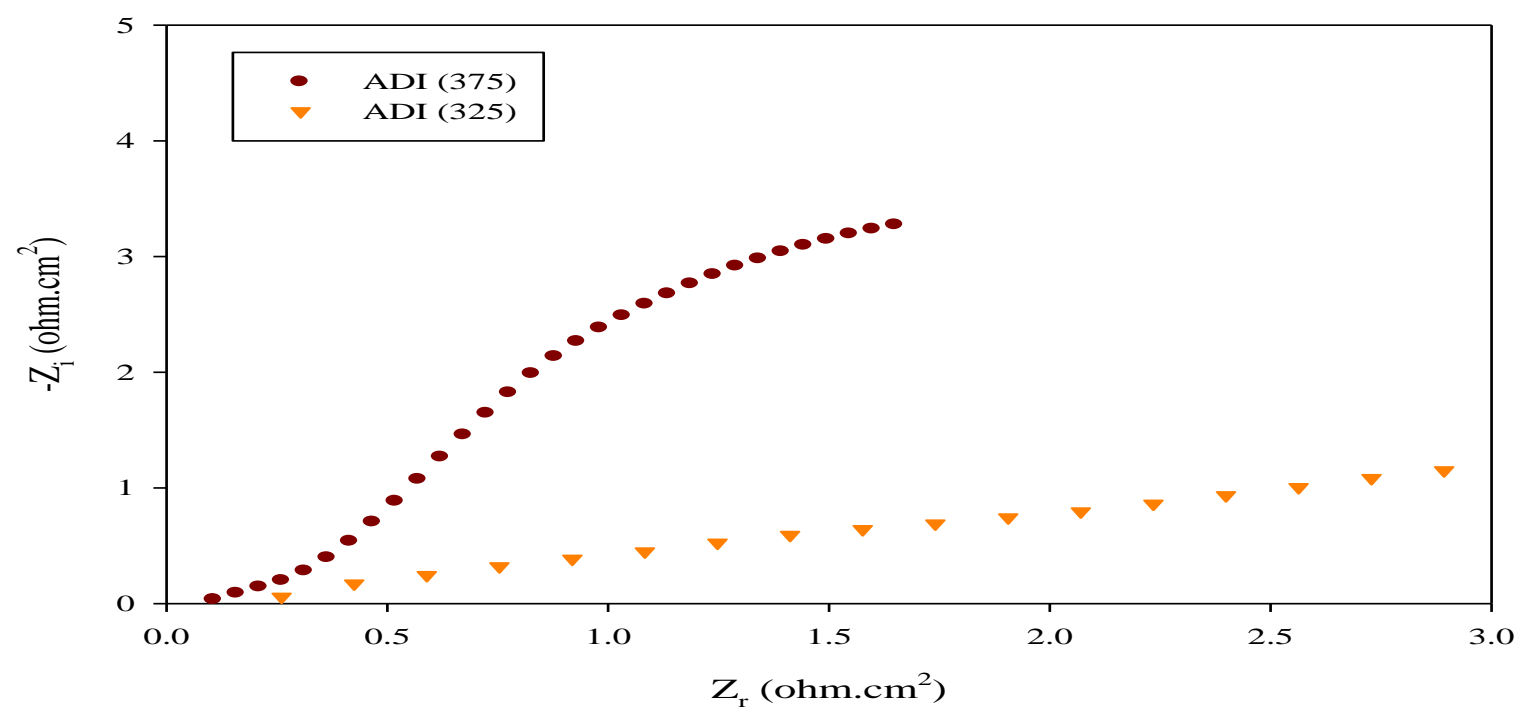

Fig 5:-Nyquist plot for ADI electrodes in 3.5\% NaCl solution

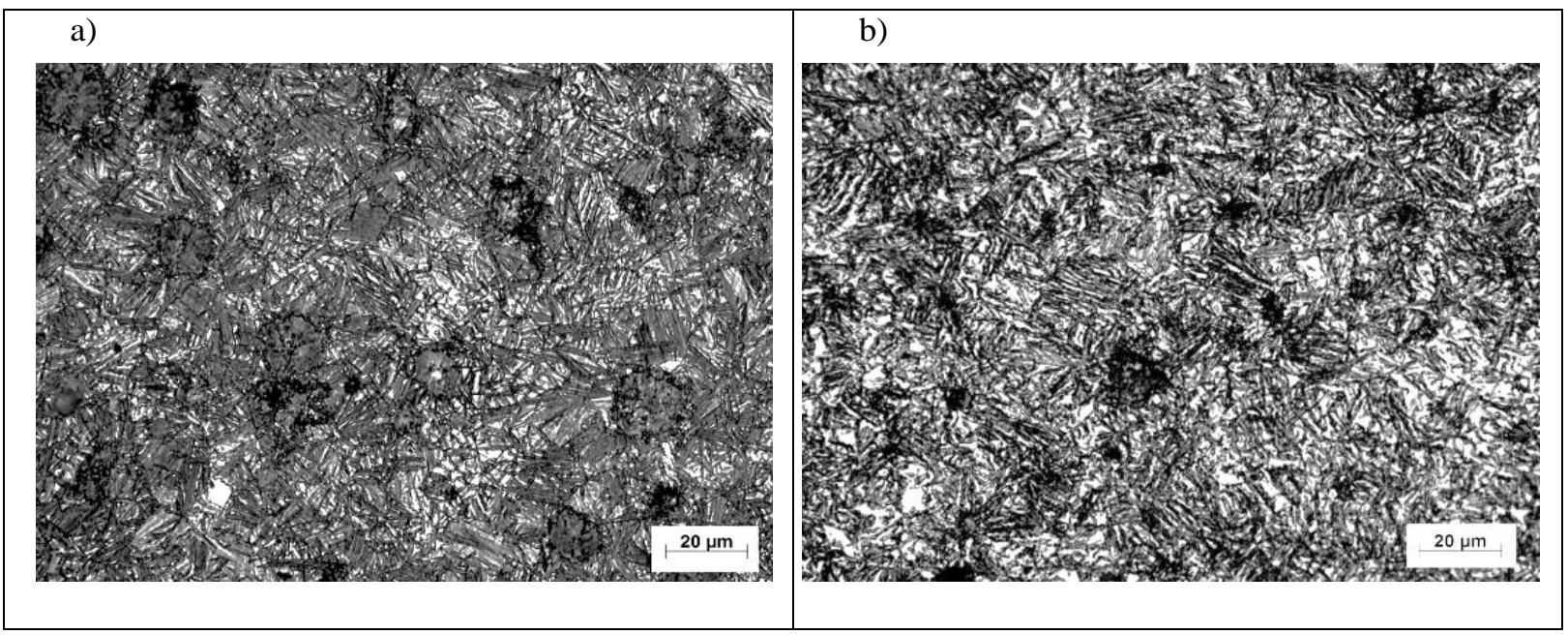

Fig 6:-SEM micrograph for $\mathrm{ADI}$ electrode $(\mathrm{a}, \mathrm{b}) 325^{\circ} \mathrm{C}$ and $375^{\circ} \mathrm{C}$ before immersion in $3.5 \% \mathrm{NaCl}$ solution. 

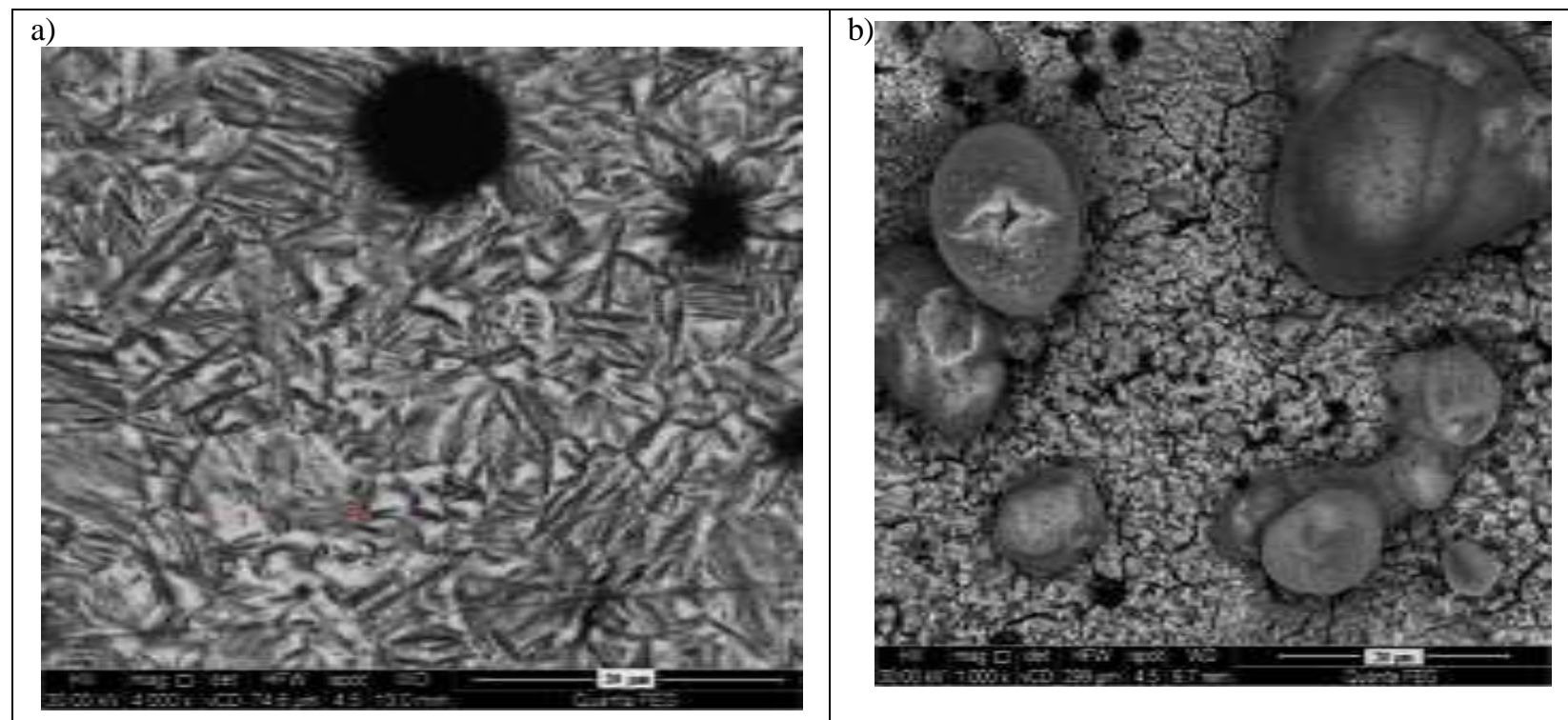

Fig 7:-SEM micrograph for ADI electrode $(\mathrm{a}, \mathrm{b}) 325^{\circ} \mathrm{C}$ and $375^{\circ} \mathrm{C}$ after immersion in $3.5 \% \mathrm{NaCl}$ solution.

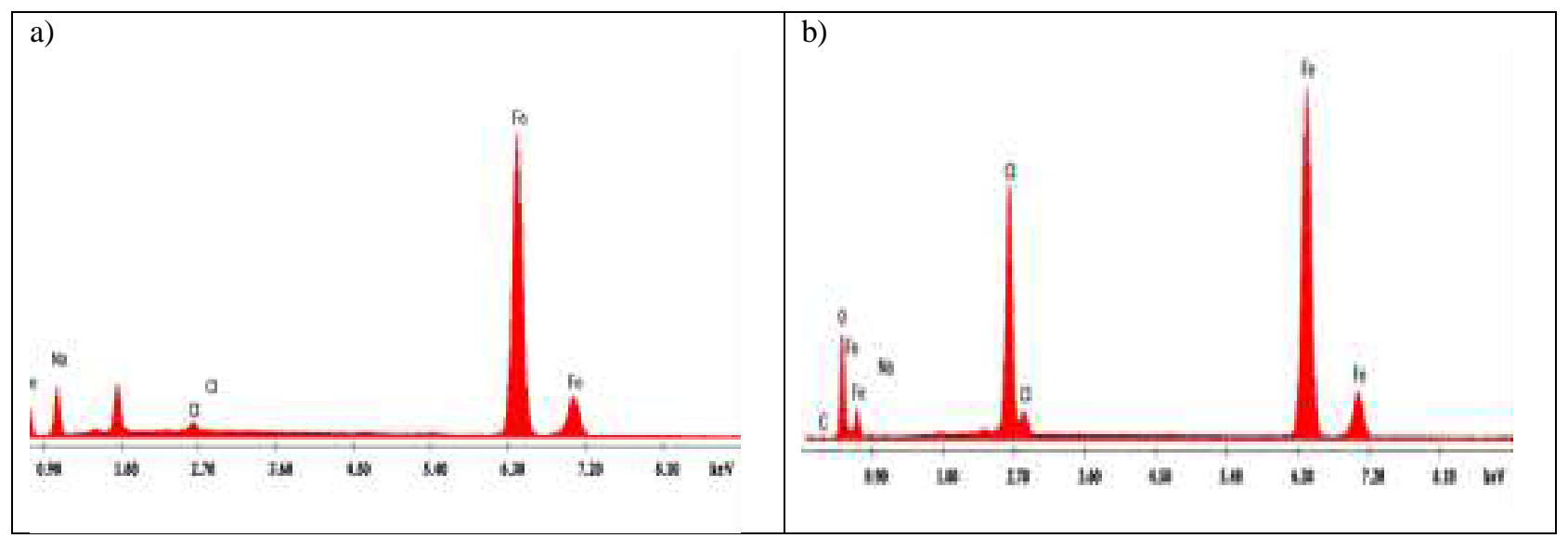

Fig 8:-EDAX spectra for ADI electrodes $(\mathrm{a}, \mathrm{b}) 325^{\circ} \mathrm{C}$ and $375^{\circ} \mathrm{C}$ in $3.5 \% \mathrm{NaCl}$ solution

\section{References:-}

1. Cheng-Hsun H., Jung-Kai L., Kuei-Liang L. and Ming-Lichen C. (2005), Materials Transactions, vol. 46, No. 6, pp. 1417-1424.

2. Kaczorowski M. and Krzyńska A. (2007), Archives of foundry engineering, vol. 7, pp. 161-166.

3. Cheng-Hsun H., Ming-Lichen (2010), Corrosion behavior of nickel alloyed and austempered ductile irons in 3.5\% sodium chloride, Corrosion Science, vol. 52, pp. 2945-2949.

4. Nofal A. (2013), Journal of Metallurgical Engineering, vol. 2.

5. Krawiec H., Lelito J., Tyrała E. and Banaś J. (2009), J. Solid State Electrochem., Vol. 13, pp. 935942,DOI 10.1007/s10008-008-0636-x.

6. Sahoo S. (2012), A Study On The Effect Of Austempering Temperature, Time and Copper Addition On The Mechanical Properties Of Austempered Ductile Iron, Master Thesis, National Institute Of Technology, Rourkela.

7. Swain S., Panda R., Dhal J., Mishra S. and Sen S.(2012), Orissa Journal of Physics, Vol. 19, No.1, pp. 73-80.

8. Cekic O., Sidjanin L., Rajnovic D. Balos and S. (2014), Met. Mater. Int., Vol. 20, No. 6, pp. 11311138, doi: 10.1007/s12540-014-6017-3.

9. Janjic M., Avdusinovic H., Jurkovic Z., Bikic F. and Savicevic S. (2016), Metalurgija, Vol. 55, No.3, pp. 325-328. 
10. Banerjee S. (2012), Effect of Chemistry on the Transformation of Austenite to Martensite for Intercritically Austempered Ductile Iron.

11. Benam A. (2015), Overseas Foundry, vol.12, pp. 54-70.

12. Afolabi A.S. (2011), Effect of austempering temperature and time on corrosion behavior of ductile iron in chloride and acidic media, Anti-Corrosion Methods and Materials, vol. 58, pp. 190-195. 